\title{
Aloe and its Effects on Cancer: A Narrative Literature Review
}

\author{
Astère Manirakiza ${ }^{a}$, Laurent Irakoze ${ }^{b}$, Sebastien Manirakiza ${ }^{c}$ \\ University Hospital Center of Kamenge, Burundi, 'bChongqing Medical University, cFaculte de Medecine de Bujumbura, Universite du Burundi \\ Correspondence to Astère Manirakiza (asteremanirakiza@yahoo.fr)
}

\begin{abstract}
Many years ago, Aloe Vera was cited to have a lot of therapeutic properties including; anti-microbial, anti-viral, anti-cancer, anti-oxidant, anti-inflammatory, skin protection, wound healing, and regulation of blood glucose and cholesterol. However, Aloe could present some side effects. This review focused on the latest discoveries regarding the therapeutic role of Aloe plant or its compounds on the acquired biological capabilities for tumour growth and progression namely; evading growth suppressor, avoiding immune destruction, enabling replicative immortality, tumour promoting inflammation, activating invasion and metastasis, inducing angiogenesis, genome instability and mutation, resisting cell death, deregulating cellular energetics and sustaining proliferating signalling. It clarified the anti-cancer activities it exerts on different types of cancer and also highlighted some pro-oncogenic pathways that can be disrupted by different compounds of Aloe.
\end{abstract}

\section{BACKGROUND}

A round 420 species of Aloe are inventoried Aworldwide, but the most popular and widely used is Aloe Barbadensis Miller (also called Aloe Vera Linne, commonly referred to as Aloe Vera). ${ }^{1,2}$ For many years, Aloe is known to have many therapeutic properties which include; anti-microbial, anti-viral, anti-cancer, anti-oxidant, anti-inflammatory, skin protection, wound healing, and regulation of blood glucose and cholesterol. ${ }^{3}$

Several studies have illustrated the role of Aloe in cancer prevention and treatment, around 75 active compounds could potentially be of therapeutic value in cancer treatment. ${ }^{4}$ Even though Aloe or its compounds is known play anti-cancer activities in many cancer types in vitro, few studies have reported this evidence. Furthermore, many in vitro studies have demonstrated the effectiveness of the whole Aloe or its compounds in inhibiting the proliferation or growth of tumours.

Whole Aloe could have an inherent anti-tumour activity because of its many compounds and could be involved in the disrupting of tumour growth and progression signalling pathways. This mechanism of action could invariably inhibit the growth of cancer cells and lead to good prognosis. However, there are some controversies about toxicities of Aloe given the recent review which reported the side effects of Aloe especially for Aloe Vera on neoplastic and non-neoplastic cells. ${ }^{1}$

Many acquired capabilities are necessary for tumour growth and progression, namely; Evading growth suppressor, Avoiding immune destruction, enabling replicative immortality, tumour promoting inflammation, activating invasion and metastasis, inducing angiogenesis, genome instability and mutation, resisting cell death, deregulating cellular energetics and sustaining proliferating signalling. ${ }^{5}$ In its anticancer activities, the aloe could act on one or more of these capabilities for tumour growth and progression.

Therefore, this narrative literature review aimed to present the effectiveness of Aloe or its compounds on cancers taking into account the acquired capabilities of Cancer.

Identification of Relevant Studies and Research Method We systematically searched on PubMed and google scholar databases. The combination of key words were Aloe and cancers, Aloe and tumours, Aloe and tumours suppressors, Aloe and cancer cytotoxicity, Aloe and cancer apoptosis, Aloe and tumour growth, Aloe and tumour proliferation, Aloe and tumour inflammation, Aloe and tumour and immune, Aloe and cancer metastasis, Aloe and cancer angiogenesis, Aloe and DNA cancer cells, Aloe and normal cells. Through identified studies, we systematically identified any compound of Aloe which has any anticancer activity. To perform deeply our research, every time the item Aloe was replaced by the identified compound in the above combination. Other studies were identified through references.

The Biological Capabilities of Cancer and Aloe Antigrowth activity of Aloe on cancer cells Aloe Vera proved its anticancer effect when it was administrated to rats with pleural tumour from hepatoma cells. ${ }^{6}$ The dichloromethane $\left(\mathrm{CH}_{2} \mathrm{Cl}_{2}\right)$ extract of cape aloe (concentrated and dried leaves of various species of Aloe, mainly Aloe ferox) caused growth inhibitory effect in Ehrlich ascites tumour cells, a decrease in DNA synthesis and an accumulation of cells in the $G_{1}$ phase. ${ }^{7}$ 


\section{Cytotoxicity of Aloe on cancer cells}

The Aloin is a natural anthracycline and it is known that anthracycline class medication such as doxorubicin is used in treatment of various types of cancer namely breast carcinoma, osteosarcoma and cancer of soft tissues, Hodgkin lymphoma, non-Hodgkin lymphoma, Solid tumour of children, lung cancers, acute and chronic leukaemia, bladder cancer, ovarian cancer and gastric cancer. ${ }^{8,9}$ Aloin's cytotoxicity effect was found and more marked in breast cancer cells without ErbB2 than those with ErbB-2.8 The Emodin, a natural anthraquinone found in Aloe ${ }^{10,11}$ and in other plants was involved in a cytotoxic activities in human myeloma. ${ }^{12}$

\section{Apoptosis and antiproliferative activities of Aloe}

When murine myeloma cells were treated by leaf extract of Aloe arborescens, the antiproliferative activity was very high while in the control group of cells, the reverse activity was observed. ${ }^{13}$ Moreover, the anti-proliferative effect of total extract from leaves of Aloe arborescens $(8 \%)$ was very high than the one of Aloe-emodin (natural hydroxyanthraquinone present in the leaves of Aloe Vera) in glioblastoma cells. ${ }^{14}$

Aloe-emodin showed its efficacy to inhibit proliferation and to induce apoptosis in many types of cancerous cells by various mechanisms (Table 1). They include human colon carcinoma cells, human oral squamous cell carcinoma, human gastric carcinoma cells, human colorectal cancer cells, human cervical cancer cells, human lung squamous carcinoma, human malignant glioma cells, human tongue squamous cancer cells, prostate cancer cells, human colon cancer cells, human nasopharyngeal carcinoma cells, human bladder cancer cells, and hepatocellular carcinoma cells. ${ }^{15-30}$

Furthermore, Aloe-emodin inhibited the proliferation of Merkel Cells Carcinoma to a significant degree and has also anti-neuroectodermal tumour activity in vitro and in vivo. ${ }^{31,32}$ Anthraquinones are involved in induction of death of human cancer cells in many studies. ${ }^{33-36}$ In Egypt, it was demonstrated that the extracts of Aloe Vera could have anti-hepatocarcinogenic effect through modulation of apoptosis. ${ }^{37}$

For hematologic cancer, it was reported that Aloe-emodin has an anti-proliferative activity in leukemia cells and in lymphoma cells. ${ }^{38,39}$ Moreover, it was found to have anticancer activity in multidrug resistant leukemia cells. ${ }^{40}$ Aloin has been reported to have an antiproliferative effect in human cervix carcinoma cells by enhancing the apoptosis $^{41}$ and has an anti-tumour effect in gastric cancer in vitro and in vivo. ${ }^{2,42}$

The Emodin exerts its anti-cancer activities in pancreatic cancer cells through declining the mitochondrial membrane potential. ${ }^{43}$ The Emodin Azide Methyl Anthraquinone Derivative (AMAD) was found to effectively block phosphorylation of Her2/neu, suppress growth, transformation and metastasis as a tyrosine kinase inhibitor, and increase the susceptibility of Her2/neu-over expressing cancer cells to standard cytotoxic therapeutic agents. This could be a potential therapeutic strategy that may block disease pathway and improve pathology in Her2/neu-over expressing cancers. ${ }^{44}$ It also has an anticancer activity on prostate cancer cells. ${ }^{45}$
Alomicin was isolated from Aloe arborescens and exerted an anticancer activity in vivo for sarcoma 180 and Ehrlich ascites cancers. In mice, it inhibited $100 \%$ of sarcoma 180 at a concentration of $100 \mathrm{mg} / \mathrm{kg}$ by the IP route (intraperitoneally) in DDS (Dorsal Dark Stripe) while 60\% of EAC were inhibited at a concentration of $2.5 \mathrm{mg} / \mathrm{kg}$ twice by the IP route. Alomicin efficiently inhibited the growth of hepatoma cells. ${ }^{2}$

Aloesin is an active compound of Aloe Vera which could arrest the cell cycle, induce apoptosis in vitro and inhibit tumour growth of ovarian cancer. ${ }^{46}$

The Di(2-Ethylhexyl) Phthalate (DEHP) extracted from Aloe Vera exerted an anti-leukaemic and anti-mutagenic effects and induced apoptosis in-vitro. ${ }^{47,48}$

It was reported that Aloe mannan is a polysaccharide extracted from Aloe arborescens which inhibited the growth of sarcoma implanted in mice. ${ }^{49}$ Administered to mouse inoculated sarcoma 180, Aloe Vera prolonged the life span of mouse. ${ }^{50}$

The mannan is extracted from Aloe Saponaria. It could inhibit tumour cell activation and proliferation and does not interfere with normal lymphocyte activation. ${ }^{51}$

The administration of the active compounds of Aloe Vera to tumour transplanted animals prolonged significantly their life. Relatively, aloe-emodin was less effective than Aloesin, Aloesin less effective than Octapeptide and Octapeptide less effective than Barbaloin. The inhibition of cells growth depended on the compounds and the type of cancer. Indeed, the growth inhibition of Ehrlich ascites carcinoma cell number when compared to the control group followed this sequence: Aloesin < Octapeptide < Aloe-emodin < Barbaloin. $^{52}$

\section{Angiogenesis of Aloe Extracts and Compounds}

Aloe-emodin was identified to have an anti-angiogenic effect. ${ }^{53}$ Indeed, oral administration of $150 \mu l$ daily dose of Aloe Vera gel to mice for 3 days after L-1 sarcoma cell grafting decreased significantly the number of newly-formed blood vessels when compared with the control group. ${ }^{54}$ Aloe-emodin could target multiple molecules responsible for angiogenesis in colon cancer cells. ${ }^{55}$ Moreover, Aloin could inhibit tumour angiogenesis by blocking STAT3 activation in colorectal cancer. ${ }^{56}$

\section{Anti-Inflammatory Activity of Aloe}

It has been demonstrated that inflammation is linked to various steps involved in tumourigenesis by supplying bioactive molecules to the tumour micro-environment such as growth factors that sustain proliferative signalling, survival factors that limit cell death, proangiogenic factors, extracellular matrix-modifying enzymes that enable angiogenesis, invasion, metastasis, and inductive signals that lead to stimulation of Epithelial Mesenchymal Transition (EMT). Moreover, inflammatory cells can release substances, especially Reactive Oxygen Species (ROS), that are actively mutagenic for nearby cancer cells which accelerate their genetic evolution toward states of intensified malignancy. 5,57 On the other hand, several studies demonstrated the anti-inflammatory activity of Aloe or its compounds in inhibiting edema in vivo. ${ }^{58-61}$ 
TABLE 1: The Compounds of Aloe and Mode of Action on Cancers

\begin{tabular}{|c|c|c|c|c|c|c|}
\hline Compounds & Country & Experiments & Effects & Type of cancer & Mode of action & References \\
\hline \multicolumn{7}{|c|}{ Whole Aloe } \\
\hline Aloe Vera & Italy & Vivo & Anticancer & $\begin{array}{l}\text { Pleural tumour from } \\
\text { hepatoma }\end{array}$ & Not described & 6 \\
\hline Aloe Vera & Egypt & Vitro & $\begin{array}{l}\text { Anticancer } \delta \\
\text { apoptosis }\end{array}$ & $\begin{array}{l}\text { hepatocellular } \\
\text { carcinoma }\end{array}$ & $\begin{array}{l}\text { Increase P53 and } \\
\text { decrease Bcl-2 genes } \\
\text { expressions }\end{array}$ & 37 \\
\hline Aloe Vera & Poland & Vivo & $\begin{array}{l}\text { Anti-angioge- } \\
\text { nesis, photoc- } \\
\text { ytotoxicity }\end{array}$ & Sarcoma & Not described & 54 \\
\hline Aloe Vera & Japan & Vitro & $\begin{array}{l}\text { Suppression } \\
\text { cell proliferation }\end{array}$ & Neuroblastoma & $\begin{array}{l}\text { Probably by suppre- } \\
\text { ssing CCND2 transcript } \\
\text { levels }\end{array}$ & 65 \\
\hline Aloe Vera & UAE & Vitro & $\begin{array}{l}\text { Inhibition of } \\
\text { cancer cell } \\
\text { growth }\end{array}$ & $\begin{array}{l}\text { Breast and cervical } \\
\text { cancer }\end{array}$ & Apoptotic pathway & 95 \\
\hline Aloe Vera & USA & Vivo & $\begin{array}{l}\text { Inhibition of } \\
\text { tumour }\end{array}$ & $\begin{array}{l}\text { Ocular Surface Squ- } \\
\text { amous Neoplasia }\end{array}$ & Not described & 105 \\
\hline $\begin{array}{l}\text { Aloe Vera } \\
\text { extract }\end{array}$ & Korean & Vitro & $\begin{array}{l}\text { Induction of } \\
\text { apoptosis }\end{array}$ & $\begin{array}{l}\text { Hepatocellular } \\
\text { carcinoma }\end{array}$ & $\begin{array}{l}\text { ATP depletion-related } \\
\text { impairment of mito- } \\
\text { chondria, which is } \\
\text { caspase-independent }\end{array}$ & 109 \\
\hline $\begin{array}{l}\text { Aloe arb- } \\
\text { orescens } \\
\text { Miller }\end{array}$ & Japan & Vivo & $\begin{array}{l}\text { Anticancer } \mathcal{E} \\
\text { ant-proliferative }\end{array}$ & Duodenal tumour & Not described & 110 \\
\hline $\begin{array}{l}\text { Aloe arb- } \\
\text { orescens }\end{array}$ & Italy & $\begin{array}{l}\text { Vitro/ } \\
\text { Vivo }\end{array}$ & $\begin{array}{l}\text { Tumour grow- } \\
\text { th inhibition }\end{array}$ & Glioblastoma & Not described & 14 \\
\hline \multicolumn{7}{|c|}{ Aloe-emodin } \\
\hline $\begin{array}{l}\text { Aloe- } \\
\text { Emodin }\end{array}$ & Taiwan & Vitro & $\begin{array}{l}\text { Antiprolifera- } \\
\text { rative }\end{array}$ & Colon carcinoma & $\begin{array}{l}\text { Inhibition of casein } \\
\text { kinase II activity, The } \\
\text { release of apoptosis- } \\
\text { inducing factor and } \\
\text { cytochrome c, Caspase- } \\
3 \text { activation }\end{array}$ & 15 \\
\hline $\begin{array}{l}\text { Aloe- } \\
\text { emodin }\end{array}$ & China & Vitro & $\begin{array}{l}\text { Antiprolifera- } \\
\text { tive, increase } \\
\text { apoptosis }\end{array}$ & $\begin{array}{l}\text { Oral squamous } \\
\text { carcinoma }\end{array}$ & $\begin{array}{l}\text { Activation of caspase- } 9 \\
\text { and caspase- } 3 \text { proteins }\end{array}$ & 16 \\
\hline $\begin{array}{l}\text { Aloe } \\
\text {-emodin }\end{array}$ & Taiwan & Vitro & $\begin{array}{l}\text { Induction of- } \\
\text { apoptosis }\end{array}$ & Gastric carcinoma & $\begin{array}{l}\text { Release the apoptosis } \\
\text {-inducing factor and } \\
\text { cytochrome c from } \\
\text { mitochondria, Activa- } \\
\text { tion of caspase-3 }\end{array}$ & 17 \\
\hline $\begin{array}{l}\text { Aloe- } \\
\text { Emodin }\end{array}$ & China & Vitro & $\begin{array}{l}\text { Suppression of } \\
\text { cell viability } \\
\text { induction of } \\
\text { apoptosis, } \\
\text { endoplasmic } \\
\text { reticulum stress }\end{array}$ & Colorectal & $\begin{array}{l}\text { Activation of factor C/ } \\
\text { EBP homologous prot- } \\
\text { ein and caspase- } 12\end{array}$ & 18 \\
\hline
\end{tabular}




\section{TABLE 1: Continued}

\begin{tabular}{|c|c|c|c|c|c|c|}
\hline Compounds & Country & Experiments & Effects & Type of cancer & Mode of action & References \\
\hline $\begin{array}{l}\text { Aloe- } \\
\text { Emodin }\end{array}$ & Poland & Vitro & $\begin{array}{l}\text { Induction of } \\
\text { apoptosis }\end{array}$ & Cervical Cancer & $\begin{array}{l}\text { Mitotic catastrophe, } \\
\text { inhibition of cell } \\
\text { division in the G2/M } \\
\text { phase, reduction of } \\
\text { viability }\end{array}$ & 19 \\
\hline $\begin{array}{l}\text { Aloe- } \\
\text { emodin } \\
\text { (Nano) }\end{array}$ & China & Vitro/Vivo & $\begin{array}{l}\text { Antiprolifer- } \\
\text { ative induction } \\
\text { of cell cycle arres } \\
\text { \& apoptosis, anti- } \\
\text { tumour growth }\end{array}$ & $\begin{array}{l}\text { Lung squamous } \\
\text { cell carcinoma } \\
\text { st } \\
\text { i- }\end{array}$ & $\begin{array}{l}\text { Cleavage of Caspase-3, } \\
\text { poly (ADP-ribose), } \\
\text { polymerase (PARP), } \\
\text { Caspase- } 8 \text { and Caspase } \\
-9 \text {, Enhanced reactive } \\
\text { oxygen species (ROS) } \\
\text { production }\end{array}$ & 20 \\
\hline $\begin{array}{l}\text { Aloe- } \\
\text { emodin }\end{array}$ & Italy & Vitro/Vivo & $\begin{array}{l}\text { Tumour growth } \\
\text { inhibition }\end{array}$ & Glioblastoma & $\begin{array}{l}\text { Reduction pAKT ph- } \\
\text { osphorylation, block } \\
\text { of cell cycle in S and } \\
\text { G2/M phase }\end{array}$ & 14 \\
\hline $\begin{array}{l}\text { Aloe- } \\
\text { emodin }\end{array}$ & Malaysia & Vitro & $\begin{array}{l}\text { Induction of } \\
\text { apoptosis and } \\
\text { cell cycle arrest } \\
\text { in S phase }\end{array}$ & $\begin{array}{l}\text { Malignant } \\
\text { glioma }\end{array}$ & $\begin{array}{l}\text { Promotion of the loss } \\
\text { of mitochondrial } \\
\text { membrane potential }\end{array}$ & 21 \\
\hline $\begin{array}{l}\text { Aloe- } \\
\text { emodin }\end{array}$ & China & Vitro & $\begin{array}{l}\text { Induction of cell } \\
\text { death through } \\
\text { S-phase arrest } \\
\text { and apoptosis }\end{array}$ & $\begin{array}{l}\text { Tongue squam- } \\
\text { ous carcinoma }\end{array}$ & $\begin{array}{l}\text { Promotion of p53, p } 21 \\
\text { and p27, Promotion of } \\
\text { the release of apoptosis- } \\
\text { inducing factor, endo- } \\
\text { nuclease G, pro-caspase } \\
-9 \text { and cytochrome c }\end{array}$ & e \\
\hline $\begin{array}{l}\text { Aloe- } \\
\text { emodin }\end{array}$ & Korea & Vitro/Vivo & $\begin{array}{l}\text { Suppression of } \\
\text { cancer progr- } \\
\text { ession }\end{array}$ & Prostate cancer & $\begin{array}{l}\text { Binding with mTORC2 } \\
\text { and inhibit its kinase } \\
\text { activity }\end{array}$ & 23 \\
\hline $\begin{array}{l}\text { Aloe- } \\
\text { emodin }\end{array}$ & India & Vitro & $\begin{array}{l}\text { Induction of } \\
\text { cell cycle arrest } \\
\text { in G2/M phase } \\
\delta \text { apoptosis }\end{array}$ & Colon cancer & Activation of Caspase- 6 & 24 \\
\hline $\begin{array}{l}\text { Aloe- } \\
\text { emodin }\end{array}$ & Taiwan & Vitro & $\begin{array}{l}\text { Induction of } \\
\text { cell cycle arrest } \\
\text { in G2/M phase } \\
\delta \text { apoptosis }\end{array}$ & $\begin{array}{l}\text { Nasopharyngeal } \\
\text { carcinoma }\end{array}$ & $\begin{array}{l}\text { Caspase- } 8 \text {-mediated } \\
\text { activation of the } \\
\text { mitochondrial death } \\
\text { pathway }\end{array}$ & 25 \\
\hline $\begin{array}{l}\text { Aloe- } \\
\text { emodin }\end{array}$ & China & Vitro & $\begin{array}{l}\text { Induction of } \\
\text { cell cycle arrest } \\
\text { in G2/M phase } \\
\delta \text { apoptosis }\end{array}$ & Bladder Cancer & $\begin{array}{l}\text { Activation of p53, } \\
\text { p21, Fas/APO-1, } \\
\text { Bax and caspase-3. }\end{array}$ & 26 \\
\hline $\begin{array}{l}\text { Aloe- } \\
\text { emodin }\end{array}$ & China & Vitro & $\begin{array}{l}\text { Induction of- } \\
\text { growth inhib- } \\
\text { itory through } \\
\text { cell cycle arrest } \\
\text { in G2/M phase }\end{array}$ & Cervical cancer & $\begin{array}{l}\text { Cell cycle arrest in } \\
\text { G2/M phase }\end{array}$ & 27 \\
\hline $\begin{array}{l}\text { Aloe- } \\
\text { emodin }\end{array}$ & Taiwan & Vitro & $\begin{array}{l}\text { Induction of } \\
\text { cell cycle arrest } \\
\text { in Gl phase and } \\
\text { apoptosis }\end{array}$ & Hepatoma & $\begin{array}{l}\text { Induction of p53 and } \\
\text { p21 expression }\end{array}$ & 28 \\
\hline
\end{tabular}


TABLE 1: Continued

\begin{tabular}{|c|c|c|c|c|c|c|}
\hline Compounds & Country & Experiments & Effects & Type of cancer & Mode of action & rences \\
\hline $\begin{array}{l}\text { Aloe- } \\
\text { emodin }\end{array}$ & USA & Vitro & $\begin{array}{l}\text { Inhibits prolif- } \\
\text { eration, and } \\
\text { induces apoptosis }\end{array}$ & $\begin{array}{l}\text { Glioma } \\
\text { is }\end{array}$ & $\begin{array}{l}\text { Delaying S phase } \\
\text { progression, reduction } \\
\text { of poly (ADP-ribose) } \\
\text { polymerase and } \\
\text { protein kinase C, } \\
\text { cleavage of caspase } 7\end{array}$ & 29 \\
\hline $\begin{array}{l}\text { Aloe- } \\
\text { emodin }\end{array}$ & Taiwan & Vitro & $\begin{array}{l}\text { Induction of } \\
\text { apoptosis }\end{array}$ & $\begin{array}{l}\text { Lung squamous } \\
\text { cell carcinoma }\end{array}$ & $\begin{array}{l}\text { Activation of caspase- } \\
3 \text {, caspase- } 8 \text {, and } \\
\text { caspase- } 9\end{array}$ & 30 \\
\hline $\begin{array}{l}\text { Aloe- } \\
\text { emodin }\end{array}$ & Italy & Vitro/Vivo & $\begin{array}{l}\text { Induction of } \\
\text { apoptosis }\end{array}$ & $\begin{array}{l}\text { Neuroectodermal } \\
\text { Tumours }\end{array}$ & Not well described & 31 \\
\hline $\begin{array}{l}\text { Aloe- } \\
\text { emodin }\end{array}$ & Israel & Vivo & $\begin{array}{l}\text { Inhibition of } \\
\text { cells prolife- } \\
\text { ration }\end{array}$ & $\begin{array}{l}\text { Merkel cell } \\
\text { carcinoma }\end{array}$ & Not described & 32 \\
\hline $\begin{array}{l}\text { Aloe- } \\
\text { emodin }\end{array}$ & Italy & Vitro & $\begin{array}{l}\text { Cells antipro- } \\
\text { liferative and } \\
\text { differentiation }\end{array}$ & Leukaemia & Not described & 38 \\
\hline $\begin{array}{l}\text { Aloe- } \\
\text { emodin }\end{array}$ & Taiwan & Vitro & $\begin{array}{l}\text { Induction of } \\
\text { cell cycle arrest } \\
\text { in G2/M phase } \& \\
\text { antiproliferative }\end{array}$ & $\begin{array}{l}\text { Promyelocytic } \\
\text { leukaemia }\end{array}$ & Not described & 39 \\
\hline $\begin{array}{l}\text { Aloe- } \\
\text { emodin }\end{array}$ & Italy & Vitro & Anticancer & $\begin{array}{l}\text { Multidrug resi- } \\
\text { stant leukaemia } \\
\text { cells }\end{array}$ & Not described & 40 \\
\hline $\begin{array}{l}\text { Aloe- } \\
\text { emodin }\end{array}$ & Spain & Vivo & $\begin{array}{l}\text { Anti-angiogen- } \\
\text { esis }\end{array}$ & Not specific & $\begin{array}{l}\text { Inhibits endothelial cell } \\
\text { proliferation }\end{array}$ & 53 \\
\hline $\begin{array}{l}\text { Aloe- } \\
\text { emodin }\end{array}$ & India & Vitro & $\begin{array}{l}\text { Inhibition of } \\
\text { cell migration/ } \\
\text { angiogenesis }\end{array}$ & Colon cancer & $\begin{array}{l}\text { Down-regulating of } \\
\text { Matrix Metalloprote- } \\
\text { inase (MMP-2/9), RhoB } \\
\text { and VEGF by reducing } \\
\text { DNA binding activity of } \\
\text { NF-kB }\end{array}$ & 55 \\
\hline $\begin{array}{l}\text { Aloe- } \\
\text { emodin }\end{array}$ & China & Vitro & $\begin{array}{l}\text { Suppression of } \\
\text { the metastasis }\end{array}$ & Breast cancer & $\begin{array}{l}\text { Inhibition of the capabi- } \\
\text { lities of invasion and } \\
\text { migration of cells proba- } \\
\text { bly }\end{array}$ & 63 \\
\hline $\begin{array}{l}\text { Aloe- } \\
\text { emodin }\end{array}$ & Italy & Vitro & $\begin{array}{l}\text { Anticancer and } \\
\text { anti-proliferation }\end{array}$ & Melanoma & $\begin{array}{l}\text { Decreasing the secretion } \\
\text { of matrix mettalloprote- } \\
\text { inase-9 }\end{array}$ & 66 \\
\hline $\begin{array}{l}\text { Aloe- } \\
\text { emodin }\end{array}$ & China & Vitro & $\begin{array}{l}\text { Arrest the cell } \\
\text { cycle in G2/M } \\
\text { phase }\end{array}$ & Gastric cancer & $\begin{array}{l}\text { Inhibition of the expres- } \\
\text { sions of protein kinase } C \\
\text { and c-myc }\end{array}$ & 67 \\
\hline $\begin{array}{l}\text { Aloe- } \\
\text { emodin }\end{array}$ & Taiwan & Vitro & $\begin{array}{l}\text { Induction of } \\
\text { cells death }\end{array}$ & $\begin{array}{l}\text { Lung non-small } \\
\text { cell carcinoma }\end{array}$ & $\begin{array}{l}\text { Decreasing Cyclic adeno- } \\
\text { sine monophosphate } \\
\text { (cAMP)-dependent prot- } \\
\text { ein kinase, protein kina- } \\
\text { se C, Bcl-2, caspase-3 } \\
\text { and p38 }\end{array}$ & 111 \\
\hline
\end{tabular}




\begin{tabular}{|c|c|c|c|c|c|c|}
\hline Compounds & Country & Experiments & Effects & Type of cancer & Mode of action & References \\
\hline $\begin{array}{l}\text { Aloe- } \\
\text { emodin }\end{array}$ & Taiwan & Vitro & $\begin{array}{l}\text { Induction of } \\
\text { DNA damage } \\
\text { and apoptosis }\end{array}$ & Lung carcinoma & $\begin{array}{l}\text { Production of generat- } \\
\text { ion of reactive oxygen } \\
\text { species and decrease in } \\
\text { the mRNA of DNA } \\
\text { repair enzymes }\end{array}$ & 69 \\
\hline $\begin{array}{l}\text { Aloe- } \\
\text { emodin }\end{array}$ & China & Vitro/Vivo & $\begin{array}{l}\text { Antineoplastic } \\
\text { (cell prolifera- } \\
\text { tion was bloc- } \\
\text { ked in Gl phase) }\end{array}$ & $\begin{array}{l}\text { Oral mucosa } \\
\text { carcinoma }\end{array}$ & $\begin{array}{l}\text { Reactive oxygen species } \\
\text { (ROS) generated and } \\
\text { up-regulation of } \\
\text { Caspase-3 }\end{array}$ & 99 \\
\hline $\begin{array}{l}\text { Aloe- } \\
\text { emodin }\end{array}$ & China & Vitro & $\begin{array}{l}\text { Inhibition of } \\
\text { tumour }\end{array}$ & Gastric cancer & Not described & 100 \\
\hline $\begin{array}{l}\text { Aloe- } \\
\text { emodin }\end{array}$ & Singapore & Vitro & $\begin{array}{l}\text { Induction of } \\
\text { apoptosis } \\
\text { and cell cycle } \\
\text { arrest in G2/M }\end{array}$ & $\begin{array}{l}\text { Hepatocellular } \\
\text { carcinoma }\end{array}$ & $\begin{array}{l}\text { Induction of higher } \\
\text { caspase-3-like activity }\end{array}$ & 68 \\
\hline $\begin{array}{l}\text { Aloe- } \\
\text { emodin }\end{array}$ & China & Vitro & Anticancer & Tongue Cancer & $\begin{array}{l}\text { Induction of DNA } \\
\text { damage and inh- } \\
\text { ibition of DNA } \\
\text { repair gene expression }\end{array}$ & 71 \\
\hline $\begin{array}{l}\text { Aloe- } \\
\text { emodin }\end{array}$ & Taiwan & Vitro & $\begin{array}{l}\text { Suppression of } \\
\text { breast cancer } \\
\text { cell proliferation }\end{array}$ & Breast Cancer & $\begin{array}{l}\text { Targeting estrogen } \\
\text { receptor protein } \\
\text { stability through } \\
\text { distinct mechanisms }\end{array}$ & 113 \\
\hline Emodin & China & Vitro & $\begin{array}{l}\text { Induction of } \\
\text { apoptosis }\end{array}$ & $\begin{array}{l}\text { Hepatocellular } \\
\text { carcinoma }\end{array}$ & $\begin{array}{l}\text { Mitochondrial apoptosis } \\
\text { pathway through cell } \\
\text { cycle arrest and ROS } \\
\text { generation }\end{array}$ & 115 \\
\hline Emodin & China & Vitro & $\begin{array}{l}\text { Induction of } \\
\text { cells death }\end{array}$ & Osteosarcomama & $\begin{array}{l}\text { Initiation of ROS- } \\
\text { dependent mito- } \\
\text { chondria-induced } \\
\text { and ROS-indepen- } \\
\text { dent endoplasmic } \\
\text { reticulum stress- } \\
\text { induced apoptosis }\end{array}$ & 116 \\
\hline Emodin & China & Vitro & $\begin{array}{l}\text { Aduction of } \\
\text { poptosis }\end{array}$ & Lung cancer & $\begin{array}{l}\text { Endoplasmic reticulum } \\
\text { stress and the TRIB } \\
3 / \mathrm{NF}-\kappa \mathrm{B} \text { pathway }\end{array}$ & 117 \\
\hline
\end{tabular}


TABLE 1: Continued

\begin{tabular}{|c|c|c|c|c|c|c|}
\hline Compounds & Country & Experiments & Effects & Type of cancer & Mode of action & eferences \\
\hline Emodin & China & $\begin{array}{l}\text { Vitro/ } \\
\text { Vivo }\end{array}$ & $\begin{array}{l}\text { Induction of } \\
\text { apoptosis }\end{array}$ & $\begin{array}{l}\text { Hepatocellular } \\
\text { carcinoma }\end{array}$ & $\begin{array}{l}\text { Mitogen-activated } \\
\text { protein kinase (MAPK) } \\
\text { and phosphoinositide } \\
\text { 3-kinase (PI3K)/AKT } \\
\text { signalling pathways }\end{array}$ & 118 \\
\hline Emodin & China & $\begin{array}{l}\text { Vitro/ } \\
\text { Vivo }\end{array}$ & $\begin{array}{l}\text { Anticancer } \\
\text { and antip- } \\
\text { roliferative }\end{array}$ & $\begin{array}{l}\text { Pancreatic cancer } \\
\text { Liver metastasis of } \\
\text { pancreatic cancer }\end{array}$ & $\begin{array}{l}\text { Inhibition of epithelial } \\
\text { mesenchymal transition } \\
\text { by raising increasing the } \\
\text { content of miR-1271 }\end{array}$ & 119 \\
\hline Emodin & China & Vitro & $\begin{array}{l}\text { Promotion of } \\
\text { the arrest of } \\
\text { cell proliferation }\end{array}$ & Lymphoma & $\begin{array}{l}\text { Increase in the UHRF1D- } \\
\text { NMT3A-TAp73/ANp73 } \\
\text { pathways. }\end{array}$ & 120 \\
\hline Emodin & China & Vitro & $\begin{array}{l}\text { Induction of } \\
\text { apoptosis }\end{array}$ & Colon cancer & $\begin{array}{l}\text { Induction of autophagy, } \\
\text { during which ROS } \\
\text { generation is of the } \\
\text { essence. }\end{array}$ & 121 \\
\hline Emodin & China & Vitro & $\begin{array}{l}\text { Induction of } \\
\text { growth inhib- } \\
\text { itionand apo- } \\
\text { ptosis }\end{array}$ & Breast cancer & $\begin{array}{l}\text { Reduction of the level of } \\
\text { Bcl-2 and increased } \\
\text { levels of cleaved caspase-3, } \\
\text { PARP, p53 and Bax }\end{array}$ & 122 \\
\hline Emodin & China & Vitro & $\begin{array}{l}\text { Induction of } \\
\text { cells growth } \\
\text { inhibition } \\
\text { and apoptosis }\end{array}$ & $\begin{array}{l}\text { Acute myeloid } \\
\text { leukaemia }\end{array}$ & $\begin{array}{l}\text { Inhibition of the PI3K/ } \\
\text { Akt signalling pathway } \\
\text { by activation of caspase } \\
\text { cascades }\end{array}$ & 123 \\
\hline Emodin & China & Vitro & $\begin{array}{l}\text { Induction of } \\
\text { apoptosis }\end{array}$ & Colon cancer & $\begin{array}{l}\text { ROS is a trigger of emodin } \\
\text { inducing apoptosis and } \\
\text { p53 expression increases } \\
\text { under oxidative stress, } \\
\text { leading to Bax-mediated } \\
\text { mitochondrial apoptosis }\end{array}$ & n 124 \\
\hline Emodin & China & Vitro & $\begin{array}{l}\text { Triggers } \\
\text { apoptosis }\end{array}$ & Neuroblastoma & $\begin{array}{l}\text { Mechanism involving } \\
\text { both reactive oxygen } \\
\text { species and nitric oxide }\end{array}$ & 125 \\
\hline Emodin & China & Vitro & $\begin{array}{l}\text { Induction of } \\
\text { apoptosis }\end{array}$ & Cervical cancer & $\begin{array}{l}\text { Intrinsic mitochondrial } \\
\text { and extrinsic death rece- } \\
\text { ptor pathways }\end{array}$ & 126 \\
\hline Emodin & India & Vitro & $\begin{array}{l}\text { Induction of } \\
\text { apoptosis }\end{array}$ & $\begin{array}{l}\text { Hepatocellular } \\
\text { carcinoma }\end{array}$ & $\begin{array}{l}\text { Blocking activation of } \\
\text { STAT3 (Signal transdu- } \\
\text { cer and activator of } \\
\text { transcription 3) }\end{array}$ & 127 \\
\hline Emodin & China & Vitro & $\begin{array}{l}\text { Induction of } \\
\text { cells growth } \\
\text { inhibition } \\
\text { and apoptosis }\end{array}$ & Breast carcinoma & $\begin{array}{l}\text { Modulation of the expr- } \\
\text { ession of apoptosis-rela- } \\
\text { ted genes }\end{array}$ & 128 \\
\hline Emodin & China & Vitro & $\begin{array}{l}\text { Induction of } \\
\text { apoptosis }\end{array}$ & Liver cancer & $\begin{array}{l}\text { A multifaceted complex } \\
\text { cascade of events }\end{array}$ & 129 \\
\hline
\end{tabular}




\section{TABLE 1: Continued}

\begin{tabular}{llllll}
\hline Compounds & Country & Experiments & Effects & Type of cancer & Mode of action \\
\hline Emodin & China & $\begin{array}{l}\text { Vitro/ } \\
\text { Vivo }\end{array}$ & $\begin{array}{l}\text { Induction of } \\
\text { apoptosis and } \\
\text { inhibition of } \\
\text { cells prolif- }\end{array}$ & Pancreatic cancer & $\begin{array}{l}\text { Declining the mitoch- } \\
\text { ondrial membrane } \\
\text { potential }\end{array}$
\end{tabular}

References

Emodin China Vitro $\quad \begin{aligned} & \text { Inhibition of } \\ & \text { cells prolife- } \\ & \text { ration and } \\ & \text { induction of } \\ & \text { apoptosis }\end{aligned}$

Prostate cancer

Inhibition of cell growth and induction of apoptosis

Emodin China Vitro

Emodin Japan Vitro

\begin{tabular}{|c|c|c|}
\hline Emodin & Taiwan & Vitro \\
\hline Emodin & Taiwan & Vitro \\
\hline
\end{tabular}

Emodin Indian Vitro

Emodin Japan Vitro

Emodin China Vitro

azide

methyl

anthraq-

uin-one

derivative

Aloin Serbia Vitro

Induction of apoptosis

Induction of cells growth inhibition and apoptosis

Induction of apoptosis

Multiple myeloma

Lung adenocarcinoma

Promyeloleukemia

Cervical cancer

Hepatocellular carcinoma apoptosis

Inhibition of cell growth and indu-

Breast cancer and lung adenocarcinoma with over expression of HER2/neu

Antiproliferative, Cervical uterine Cell cycle arrest in carcinoma the $S$ phase, Apoptosis ction of apoptosis
Androgen receptor and and p53-p21 pathways and the mitochondrial pathway.

Inhibition of phosphorylation of P210 protein, down-regulation of P210 protein expression and activation of caspase- 3

Inhibition of Akt [Protein kinase B (PKB)] signal pathway

Inhibition of interleukin -6-induced JAK2/STAT3 pathway

Reactive oxygen speciesdependent mitochondrial signaling pathway

Activation of caspase 3 cascade but independent of reactive oxygen species production

Caspase-dependent and presumably through the mitochondrial pathway, by the activation of caspases-3, -9 and cleavage of poly (ADP-ribose) polymerase

Enhancement of generation of ROS, DeltaPsim disruption and caspase activation

Disruption of the PI3K/ Akt-dependent pathway

Changes in the activity of almost all anti-oxidant enzyme 


\begin{tabular}{|c|c|c|c|c|c|c|}
\hline Compounds & Country & Experiments & Effects & Type of cancer & Mode of action & rences \\
\hline \multicolumn{7}{|c|}{ Aloin } \\
\hline Aloin & China & $\begin{array}{l}\text { Vitro } \\
\text { Vivo }\end{array}$ & $\begin{array}{l}\text { Inhibit of } \\
\text { tumour angio- } \\
\text { genesis growth }\end{array}$ & Colorectal cancer & $\begin{array}{l}\text { Suppression of activation } \\
\text { of VEGF receptor (VEGFR) } \\
2 \text { and STAT3 phosphory- } \\
\text { lation in endothelial cells }\end{array}$ & 56 \\
\hline $\begin{array}{l}\text { Aloin } \\
\text { (Barbaloin) }\end{array}$ & China & $\begin{array}{l}\text { Vitro/ } \\
\text { Vivo }\end{array}$ & $\begin{array}{l}\text { Reduction of } \\
\text { gastric cancer } \\
\text { cell viability } \& \\
\text { induction of } \\
\text { apoptosis }\end{array}$ & Gastric cancer & $\begin{array}{l}\text { Induction of autophagy } \\
\text { and ROS generation }\end{array}$ & 42 \\
\hline Aloin & Italy & Vitro & $\begin{array}{l}\text { Antineoplastic } \\
\mathcal{E} \text { antimetastatic }\end{array}$ & Melanoma & $\begin{array}{l}\text { Induction of melanoma } \\
\text { cell differentiation }\end{array}$ & 97 \\
\hline \multicolumn{7}{|c|}{ Acemannan } \\
\hline $\begin{array}{l}\text { Acema- } \\
\text { nnan }\end{array}$ & USA & Vivo & Anticancer & Fibrosarcoma & $\begin{array}{l}\text { Macrophage activation } \\
\text { and release of tumour } \\
\text { necrosis factor, interl-, } \\
\text { eukin-1 and interferon }\end{array}$ & 88 \\
\hline $\begin{array}{l}\text { Acema- } \\
\text { nnan }\end{array}$ & USA & Vivo & $\begin{array}{l}\text { Infiltration of } \\
\text { tumour by } \\
\text { immune system } \\
\text { cells, became } \\
\text { necrotic \& } \\
\text { regressed }\end{array}$ & Sarcoma & $\begin{array}{l}\text { Stimulation of synthesis } \\
\text { of monokines resulted } \\
\text { in the initiation of } \\
\text { immune attack, necrosis, } \\
\text { and regression of tumour }\end{array}$ & 91 \\
\hline $\begin{array}{l}\text { Aloe } \\
\text { mannan }\end{array}$ & Japan & Vivo & $\begin{array}{l}\text { Inhibition of } \\
\text { tumour }\end{array}$ & Sarcoma & Not described & 49 \\
\hline \multicolumn{7}{|c|}{ Others } \\
\hline $\begin{array}{l}\text { Dichlo- } \\
\text { romethane }\end{array}$ & Japan & Vitro & $\begin{array}{l}\text { Cells growth } \\
\text { inhibition }\end{array}$ & $\begin{array}{l}\text { Ehrlich ascites } \\
\text { tumour }\end{array}$ & $\begin{array}{l}\text { Decrease of cells in the } \\
\mathrm{S} \text { and G2/M phase of } \\
\text { the cell cycle; inhibition } \\
\text { of DNA synthesis }\end{array}$ & 7 \\
\hline Aloesin & China & $\begin{array}{l}\text { Vitro/ } \\
\text { Vivo }\end{array}$ & $\begin{array}{l}\text { Induction of } \\
\text { apoptosis, } \\
\text { inhibition of } \\
\text { tumour growth, } \\
\text { migration and } \\
\text { invasion }\end{array}$ & Ovarian cancer & $\begin{array}{l}\text { Inhibition of the mitogen } \\
\text { activated protein kinase } \\
\text { (MAPK) signalling } \\
\text { pathway }\end{array}$ & 46 \\
\hline $\begin{array}{l}\text { Di } \\
\text { (2-ethylh- } \\
\text { exyl) } \\
\text { phthalate } \\
\text { (DEHP) }\end{array}$ & Korea & Vitro & $\begin{array}{l}\text { Growth } \\
\text { inhibition }\end{array}$ & Leukaemia & Not described & 47 \\
\hline $\begin{array}{l}\text { Diethy- } \\
\text { lhexyl- } \\
\text { phthalate }\end{array}$ & Korea & Vitro & $\begin{array}{l}\text { Induction of } \\
\text { apoptosis }\end{array}$ & Leukaemia & Not described & 48 \\
\hline
\end{tabular}




\section{Effects of Aloe on Regulating Glucose Metabolism}

Cancer cells are able to reprogram their glucose metabolism by up-regulating glucose transporters, especially GLUT1, which significantly increases glucose import into the cytoplasm. These have been demonstrated by many studies. ${ }^{5}$ Recently, it was proven that aloe-emodin, one of the compounds of Aloe inhibited glucose metabolism by reducing GLUT1 expression in cervical cancer Cells. ${ }^{62}$

\section{Effects of Aloe on Cell Metastasis}

Aloe-emodin could suppress the metastasis of breast cancer cells. The mechanisms is not clearly elucidated and may be related to the inhibition of invasion and migration of cells. ${ }^{63}$ It could also decrease protein levels of tumour metastasis-related proteins in human tongue cancer cells. ${ }^{64}$ Aloe Vera could suppress the cells proliferation in human neuroblastoma cell. ${ }^{65} \mathrm{Al}-$ oe-emodin was involved in inhibition of key regulatory molecules in colon cancer cell migration. ${ }^{55}$ The antiproliferative activity of Aloe-emodin was also found in-melanoma and gastric cancer cells. ${ }^{66,67}$ In human hepatocellular carcinoma cells, Aloe-Emodin and its homologue emodin were able to decrease cell migration. ${ }^{68}$

\section{Effects of Aloe on Deoxyribo Nucleic Acid (DNA Of Cancer Cells}

Aloe-emodin could induced DNA damage in human lung carcinoma cells through generation of reactive oxygen species. ${ }^{69}$ It was also observed in leukemia cells, breast cancer cells, colon cancer cells, glioblastoma multiform cells and human embryonic kidney cells ${ }^{70}$. In human tongue cancer cells, this DNA damage by Aloe-emodin was followed by inhibition of DNA repair of cancer cells. ${ }^{64,71}$

\section{Effects of Aloe on Normal Cells in Patients with Cancer}

There is no cytotoxic activity towards the normal cells caused by Aloe-emodin ${ }^{70}$. The analysis of some studies revealed that chemotherapy is substantially better tolerated in patients concomitantly treated with Aloe. ${ }^{72}$ The $\mathrm{IC}_{50}$ of the extract of the leaf of Aloe Vera against breast cancer cell line was almost 15 times lower than that of Aloe Vera leaf extract against non-cancerous cell line..$^{73}$ One randomised study found that oral Aloe Vera gel can reduce radiation-induced mucositis in head-and-neck cancer patients but did not improve tolerance to headand-neck radiotherapy, decrease mucositis, reduce soreness, or improve patient well-being. ${ }^{74}$ However, it was a potential choice, for palliative treatment for patients undergoing treatment of head and neck cancer and prevent oral complications as well as oral Aloe Vera juice. ${ }^{75,76}$

On the other hand, Aloe Vera gel did not significantly reduce radiation-induced skin side effects. However, aqueous cream was useful in reducing dry desquamation and pain related to radiation therapy in breast cancer. $^{77}$ In neuroectodermal tumours, Aloe Vera does not inhibit the proliferation of normal fibroblasts nor that of hemopoietic progenitor cells. ${ }^{31}$ The molecules in fluid fractions from leaf of Aloe Vera were found to markedly promote attachment and growth of non-neoplastic human cells, but not tumour cells. This attachment and growth of human cells is evident in natural Aloe Vera more than in commercial preparations may be owing to sub- stances introduced during commercial processing. ${ }^{78}$

It has been reported that Aloe vera preparations could cause diarrhoea, hypokalemia, pseudomelanosis coli, kidney failure, phototoxicity, hypersensitive reactions and its whole leaf extracts were considered as carcinogenic in rats. ${ }^{1}$

\section{Effects of Aloe on Telomerase Activity}

Telomerase is an enzyme in control of the synthesis of telomeres and is activated in many types of cancers. In cancer cells, it promotes the replication, proliferation and metastasis of cancer cells. ${ }^{79}$

G-quadruplex formation might inhibit telomerase activity in most cancer cells by locking the single-stranded telomeric substrate into an inactive conformation, which is neither recognized nor elongated by telomerase. The anthraquinones were one of the first ligands found capable of stabilising G-quadruplexes and inhibiting telomerase. Aloe-emodin, Aloe-Emodin Derivative 3 (AED3) and emodin could play the same role as long as they belong to anthraquinones. Moreover, Emodin, Aloe-emodin and AED3 induced strong fluorescence quenching of 12C5TG-AgNC which indicate that they are G-quadruplex-interactive ligands. ${ }^{80,81}$ Furthermore, it has been reported that the Di-2-Ethylhexyl Phthalate should decrease telomerase activity and increase TNF in the rat testis. ${ }^{82}$ In the recent study, it has been demonstrated that Aloe-emodin is a competitive inhibitor of telomerase and a G-quadruplex structure stabiliser in breast cancer cells. It decreases the telomerase activity by competing with dNTP for binding to the enzyme active site and stabilising the telomeric G-quadruplex structure. ${ }^{83}$

\section{Aloe and Cellular Immunity}

A randomised study assessing chemotherapy alone versus chemotherapy plus Aloe arborescens in patients with metastatic cancer have been performed. It was reported that the lymphocyte mean number observed after therapy in patients concomitantly treated with aloe was significantly higher than that observed in the group treated with chemotherapy alone. ${ }^{72}$ It was also reported that aloe-emodin increased the levels of interleukin (IL)-lbeta and tumour Necrosis Factor (TNF)-alpha. ${ }^{84}$

Aloctin A (Alo A) is an active substance of Aloe arborescens Miller. The treatment effects of this compound have been described in vivo and in vitro on the immune response of murine and human lymphoid cells..$^{85}$ Alo A was also involved in inhibiting the growth of induced fibrosarcoma in mice and was not directly cytotoxic to tumour cells in vitro. ${ }^{86}$ Aloctin A is one of lectin plant found in Aloe. Lectin were identified to have cytotoxic effects on the tumour cell surface augments tumour-specific by enhancing immunity through activation of T cells. ${ }^{87}$

Acemannan is the most active polysaccharides found in Aloe Vera. It has been reported that this compound should exert its antitumor activity through macrophage activation and the release of tumour necrosis factor, interleukin-1, and interferon. ${ }^{88,89}$ The same substance Acemannan, was involved in increasing immunity in mouse whose immune systems had been damaged by radiation. ${ }^{90}$

Another study indicated that intraperitoneal treatment with Acemannan stimulate synthesis of monokines resulted in the initiation of immune attack (includ- 
ing interleukin-1 and tumour necrosis factor), necrosis, and regression of implanted sarcomas in mouse. ${ }^{91}$ Moreover, Acemanna (CarraVet Acemannan Immunostimulant) has been approved as a biologic treatment of fibrosarcoma in cats and dogs by the USDA. ${ }^{2}$

\section{Aloe in combination with other cancer therapies}

Aloe-emodin enhanced the activities of tamoxifen, cisplatin, doxorubicin, cyclophosphamide and 5-fluorouracil $^{92-94}$ and Aloes Vera acts synergistically with cisplatin to inhibit proliferation of human breast and cervical cancer cells. ${ }^{95}$ Furthermore, some specific compounds extract from the leaf of Aloe Vera (such as Aloe-emodin, 7-hydroxy-2,5 dimethyl chromone, Beta-sitosterol, etc.) possess higher binding affinity toward estrogen alpha receptor than standard tamoxifen..$^{73}$ Aloe-emodin increased the radio-sensitivity of human cervical cancer cells in vitro, inhibited their proliferation and, in combination with radiation, it induced the apoptosis. ${ }^{96}$ Aloin, another compound of Aloe enhanced the antineoplastic activity of cisplatin in melanoma cells ${ }^{97}$ and the emodin sensitised the hepatocellular carcinoma cells to the anti-tumour activity of Sorafenib (tyrosine kinase inhibitor). ${ }^{98}$

Aloe-emodin induced cell apoptosis and leads to cell death in vitro and in vivo while associated with photodynamic therapy it enhanced killing effect of human oral mucosa carcinoma, human gastric cancer cells and breast cancer cells. ${ }^{99-101}$

In their study, Lissoni P. and his colleagues compared chemotherapy alone with chemotherapy associated with Aloe. The complete response was achieved in 3\% (4/121) of patients treated with chemotherapy alone versus $10 \%$ (12/119) of patients treated with chemotherapy + Aloe while partial response was achieved in 16\% (19/121) of patients treated with chemotherapy alone versus $23 \%$ (28/119) of patients treated with chemotherapy + Aloe. The disease stability was observed in 31\% (37/121) for patients treated with chemotherapy alone and in $34 \%$ (40/119) for patients treated with chemotherapy + Aloe. The disease progression was significantly higher in the patients treated with chemotherapy alone than in the group treated with chemotherapy + Aloe [50\% (61/121) VS. 33\% (39/119)]. ${ }^{72}$

One randomised study found that oral Aloe Vera gel did not reduce radiation-induced mucositis in head-andneck cancer patients. ${ }^{74}$ The Aloe Vera had no positive effect on prevalence or severity of radiation dermatitis in in breast cancer patients treated with radiation therapy. ${ }^{102}$ However, it was considered as an alternative agent in the treatment of mucositis induced by radiation in patients with head and neck cancers. ${ }^{103}$

Another study compared the administration of melatonin (hormone primarily released by the pineal gland that regulates the sleep-wake cycle) alone versus melatonin + Aloe Vera in patients suffering from various advanced solid tumours and for whom no effective standard anticancer therapies are available. It found a partial response achieved in 2/24 patients treated with melatonin plus Aloe and in $0 / 24$ patients treated with melatonin alone. The disease stability was achieved in 12/24 for patients treated with melatonin plus aloe and in 7/26 for patients treated with melatonin alone. The percentage of stabilised patients was significantly higher in the group treated with melatonin + aloe than in the melatonin group (14/24 vs. 7/26). The 1 -year survival patients was significantly higher in patients treated with melatonin plus aloe (9/24 vs. 4/26). ${ }^{104}$

It has been reported, a 64-years-old woman treated with topical Aloe Vera for ocular surface squamous neoplasia. ${ }^{105}$

In combination with surgery and radiation therapy, the Acemannan was administrated to canine (dog-like mammals) and feline (member of the cat family) suffering from fibrosarcoma and the results were impressive. While these animals had recurring disease failing previous treatment, a poor prognosis for survival, or both; the Acemannan treatment modified the tendency. ${ }^{106}$

Aloe Vera given concomitantly with honey can modulate tumour growth by reducing cell proliferation and reducing tumour weight. In fact, Aloe Vera may reduce tumour mass and metastasis rates, while honey may inhibit tumour growth. ${ }^{107}$

Emodin enhanced the antitumour effect of gemcitabine in pancreatic cancer and it could contribute to reduced chemo-resistance. ${ }^{108}$

\section{CONCLUSION}

Whether the whole Aloe or its compounds are considered, we found through different articles that Aloe is a medicinal plant that has acted well against many types of cancer, namely cervix carcinoma, breast carcinoma, osteosarcoma, cancer of soft tissues, Hodgkin lymphoma, non-Hodgkin lymphoma, solid tumour of children, lung cancers, acute and chronic leukaemia, bladder cancer, ovarian cancer, gastric cancer, colon carcinoma, oral squamous cell carcinoma, colorectal cancer, lung squamous carcinoma, malignant glioma, tongue squamous cancer, prostate cancer, nasopharyngeal carcinoma, bladder cancer, hepatocellular carcinoma, Merkel cells carcinoma, leukaemia and in lymphoma, pancreatic cancer, prostate cancer, myeloma, sarcoma, hepatoma, ovarian cancer, neuroblastoma, melanoma, lung carcinoma, glioblastoma multiform, fibrosarcoma, ocular surface squamous neoplasia, pleural tumour from hepatoma, duodenal tumour, glioblastoma, hepatoma, neuroectodermal tumours, promyelocytic leukaemia, non-small cell lung carcinoma, oral mucosa carcinoma, pancreatic cancer, liver metastasis of pancreatic cancer, lymphoma, acute myeloid leukaemia, liver cancer, multiple myeloma, lung adenocarcinoma, promyeloleukeamia, breast cancer and lung adenocarcinoma with overexpression of HER2/neu, Ehrlich ascites tumour and fibrosarcoma.

Moreover, this review points out the fact that Aloe or at least one of its compounds could interrupt the pro-growth signalling pathways of cancer and this is the first time to show the therapeutic effect of Aloe on cancer based on biological capabilities of cancer. This can lead to development of a drug based on the whole Aloe or their compounds

In fact, a part from whole Aloe, 9 different compounds of different Aloe have been identified to have anticancer activities involving many pathways. Anticancer activity depended variably on compounds types, time and type of cancer. Given the anticancer effects of its compounds taken separately or the whole leaf, Aloe exerts the anticancer effects through many mechanisms which 
could act synergistically. There is a high potential thatwhole Aloe or the combination of some of its compounds could be a chemotherapy based treatment which could have a therapeutic value in chemotherapy of different types of cancers with no or minimum side effects.

However, we realised that there are few studies conducted on Aloe illustrating its molecular suppressive activity of cancer. It is for instance the role of Aloe on inflammation, regulating glucose metabolism in cancer cells. Only 2 databases were explored and moreover many of these studies were conducted on Aloe vera despite the fact that there are many species of Aloe and this is one of the weak points of this review. There is the need for more studies especially in vivo to be undertaken to examine the molecular activities of the different species of Aloe so that more effective therapeutics could be designed.

Acknowledgment: Our thanks are addressed to Annociate Mpfukamensabe for her facilities to access the internet. Special acknowledge are addressed to Quist Kanyomse for his contribution in English correction.

\section{REFERENCES}

1. Guo X, Mei N. Aloe vera: A review of toxicity and adverse clinical effects.J Environ Sci Health Part C Environ Carcinog Ecotoxicol Rev. 2016;34(2):77-96. doi:10.1080/10590501.20 16.1166826. Medline

2. Reyinolds T. Aloes: The genus Aloe (Medicinal and Aromatic Plants - Industrial Profiles) Vol 1 ed.: CRC Press; 2004

3. Gao Y, Kuok Kl, Jin Y, Wang R. Biomedical applications of Aloe vera. Crit Rev Food Sci Nutr. 2018;1-13 Medline.

4. Cathcart P, Stebbing J. Aloe vera, a natural cancer soother?Lancet Oncol. 2016;17(4):421. doi:10.1016/S14702045116)00161-3. Medline

5. Hanahan D, Weinberg RA. Hallmarks of cancer: the next generation. C'ell. $2011 ; 144(5): 646-674$.doi:10.1016/i. cell.2011.02.013. Medline

6. Corsi MM, Bertelli AA, Gaja G, Fulgenzi A, Ferrero ME. The therapeutic potential of Aloe Vera in tumor-bearing rats. Int J Tissue React. 1998;20(4): 1 15-118 Medline.

7. Kametani S, Oikawa T, Kojima-Yuasa A, et al. Mechanism of growth inhibitory effect of cape aloe extract in ehrlich ascites tumor cells.J Nutr Sci Vitaminol (Tokyo). 2007;53(6):540-546. doi: $10.3177 /$ insv. 53.540. Medline

8. Esmat AY, Tomasetto C, Rio MC. Cytotoxicity of a natural anthraquinone (Aloin) against human breast cancer cell lines with and without ErbB-2: Topoisomerase II-alpha coamplification. Cancer Biol Ther. 2006;5(1):97-103. doi:10.4161/cbt.5.1.2347. Medline

9. Young RC, Ozols RF, Myers CE. The Anthracycline Antineoplastic Drugs. 1981;305(3):139-153.

10. IARC. Some Drugs and Herbal Products. Vol 108. Lyon: WHO; 2016.

11. Ross YA. Medicinal Plants of the World. Vol 1.2ed. NewYork:Humana Press Inc; 2003.

12. Muto A, Hori M, Sasaki Y, et al. Emodin has a cytotoxic activity against human multiple myeloma as a Janus-activatedkinase 2 inhibitor.Mol Cancer Ther. 2007;6(3):987-994. doi: 10.1158/1535-7163.MCT-06-0605. Medline

13. Ceccarelli D, Ovidi E, Triggiani D, et al. Antiproliferative activity of Aloe arborescens leaf skin extracts tested on murine myeloma cells: Cytological studies and chemical investigations. Med Aromat Plant Sci Biotechnol. 201 2;6:3 1-36.

14. Arcella A, Oliva MA, Staffieri $S$, et al. Effects of aloe emodin on U87MG glioblastoma cell growth: In vitro and in vivo study. Environ Toxicol. 2018;33(11):1160-1167. doi:10.1002/ tox.22622. Medline

15. Lin $K Y$, Uen $Y H$. Aloe-emodin, an anthraquinone, in vitro inhibits proliferation and induces apoptosis in human colon carcinoma cells. Oncol Lett. 2010;1(3):541-547.doi:10.3892/ ol 00000096. Medline

16. LiQ, WenJ, YuK, et al. Aloe-emodin induces apoptosis in human oral squamous cell carcinoma SCC 15 cells.BMC Complement Altern Med. 2018;18(1):296. doi:10.1186/s12906-0182353-z. Medine

17. ChenSH, LinKY, ChangCC, FangCL, LinCP. Aloe-emodin-induced apoptosis in human gastric carcinoma cells. Food and chemical toxicology : an international journal published for the British Industrial Biological Research Association.2007;45(1 1):2296-2303.

18. Cheng C, Dong W. Aloe-Emodin Induces Endoplasmic Reticulum Stress-Dependent Apoptosis in Colorectal Cancer Cells.Med Sci Monit. 2018;24:6331-6339.doi:10.12659/MSM.908400. Medline

19. Trybus W, Kró IT, Trybus E, Stachurska A, Kopacz-Bednarska A, Kró IG. Induction of Mitotic Catastrophe in Human Cervical Cancer Cells After Administration of Aloe-emodin. Anticancer Res. 2018;38(4):2037-2044 Medline.

20. Wu YY, Zhang JH, Gao JH, Li YS. Aloe-emodin (AE) nanoparticles suppresses proliferation and induces apoptosis in human lung squamous carcinoma via ROS generation in vitro and in vivo.Biochem Biophys Res Commun. 2017;490(3):601-607. doi: 10.1016/i.borc.2017.06.084. Medline

21. Ismail S, Haris K, Abdul Ghani ARI, Abdullah JM, Johan MF, Mohamed Yusoff AA. Enhanced induction of cell cycle arrest and apoptosis via the mitochondrial membrane potential disruption in human U87 malignant glioma cells by aloe emodin.J Asian Nat Prod Res. 2013; 15(9): 1003-1012. doi:10.1080/10286020 .2013.818982. Medline

22. Chiu TH, Lai WW, Hsia TC, et al. Aloe-emodin induces cell death through S-phase arrest and caspase-dependent pathways in human tongue squamous cancer SCC-4 cells. Anticancer Res. 2009;29(1 1):4503-4511 Medline.

23. Liu K, Park C, Li S, et al. Aloe-emodin suppresses prostate cancer by targeting the mTOR complex 2. Carcinogenesis. $2012 ; 33(7): 1406-1411$.doi: 10.1093/carcin/bgs 156. Medline

24. Suboi P, Babykutty S, Srinivas P, Gopala S. Aloe emodin induces G2/M cell cycle arrest and apoptosis via activation of caspase-6 in human colon cancer cells. Pharmacology. 2012;89(1-2):9198. doi: 10.1159/000335659. Medline

25. Lin ML, Lu YC, Chung JG, et al. Aloe-emodin induces apoptosis of human nasopharyngeal carcinoma cells via caspase-8-mediated activation of the mitochondrial death pathway. Cancer Lett. $2010 ; 291(1): 46-58$. doi:10.1016/i.canlet.2009.09.016. Medline

26. Lin JG, Chen GW, Li TM, Chouh ST, Tan TW, Chung JG. Aloe-emodin induces apoptosis in T24 human bladder cancer cells through the p53 dependent apoptotic pathway.J Urol. 2006; 175(1):343347.doi: 10.1016/50022-5347105/00005-4. Medline

27. Guo J, Xiao B, Liu Q, Zhang S, Liu D, Gong Z. Anticancer effect of aloe-emodin on cervical cancer cells involves $G$, M arrest and induction of differentiation. Acta Pharmacol Sin. 2007;28(1 2): 1991 1995. doi:10.1111/i.1745-7254.2007.00707.x. Medline 
28. Kuo PL, Lin TC, Lin CC. The antiproliferative activity of aloe-emodin is through p53-dependent and p2 1-dependent apoptotic pathway in human hepatoma cell lines. Life Sci. 2002:71(16): 18791892.doi: 10.1016/S0024-3205/02101900-8. Medline

29. Acevedo-DuncanM, RussellC, PatelS, PatelR. Aloe-emodin modulates PKC isozymes, inhibits proliferation, and induces apoptosis in U-373MG glioma cells. Int Immunopharmacol. 2004:4(1 4): 1775 1784 .doi: 10.1016/i.intimp.2004.07.012. Medline

30. Lee HZ, Hsu SL, Liu MC, Wu CH. Effects and mechanisms of aloe-emodin on cell death in human lung squamous cell carcinoma. Eur J Pharmacol. 2001;43 1 (3):287-295.doi:10.1016/S00142999101101467-4. Medline

31. Pecere T, Gazzola MV, Mucignat C, et al. Aloe-emodin is a new type of anticancer agent with selective activity against neuroectodermal tumors. Cancer Res. 2000;60(1 1):2800-2804 Medline.

32. Wasserman L, Avigad S, Beery E, Nordenberg J, Fenig E. The effect of aloe emodin on the proliferation of a new merkel carcinoma cell line. Am J Dermatopathol. 2002;24(1): 17-22. doi: 10.1097/00000372-200202000-00003. Medline

33. Choi HK, Ryu H, Son AR, et al. The novel anthraquinone derivative IMP1338 induces death of human cancer cells by p53-independent $\mathrm{S}$ and $\mathrm{G} 2 / \mathrm{M}$ cell cycle arrest. Biomedicine \& pharmacotherapy = Biomedecine \& pharmacotherapie. 20 16;79:308-314.

34. Yeap S, Akhtar MN, Lim KL, et al. Synthesis of an anthraquinone derivative (DHAQC) and its effect on induction of $G 2 / M$ arrest and apoptosis in breast cancer MCF-7 cell line.Drug Des Devel Ther. 2015;9:983-992 Medline.

35. Aziz MYA, Omar AR, Subramani T, et al. Damnacanthal is a potent inducer of apoptosis with anticancer activity by stimulating p53 and p2 1 genes in MCF-7 breast cancer cells. Oncol Lett. 2014;7(5): 1479-1484. doi:10.3892/ol.2014.1898. Medline

36. Huang Q, Lu G, Shen HM, Chung MCM, Ong CN. Anti-cancer properties of anthraquinones trom rhubarb. Med Res Rev. 2007;27(5):609-630. doi:10.1002/med.20094. Medline

37. Shalabi M, Khilo K, Zakaria MM, Elsebaei MG, Abdo W, Awadin WJAP Jo TB. Anticancer activity of Aloe vera and Calligonum comosum extracts separetely on hepatocellular carcinoma cells. $2015 ; 5(5): 375-381$.

38. Tabolacci C, Oliverio S, Lentini $A$, et al. Aloe-emodin as antiproliferative and differentiating agent on human U937 monoblastic leukemia cells.Life Sci. 2011 1;89(21-22):812-820. doi:10.1016/i.Ifs.2011.09.008. Medline

39. Chen HC, Hsieh WT, Chang WC, Chung JG. Aloe-emodin induced in vitro $\mathrm{G} 2 / \mathrm{M}$ arrest of cell cycle in human promyelocytic leukemia HL-60 cells. Food and chemical toxicology : an international journal published for the British Industrial Biological Research Association.2004;42(8):1251-1257.

40. Grimaudo S, Tolomeo M, Gancitano R, DAlessandro N, Aiello E. Effects of highly purified anthraquinoid compounds from Aloe vera on sensitive and multidrug resistant leukemia cells. Oncol Rep. 1997;4(2):341-343. doi:10.3892/or.4.2.341. Medline

41. Nićiforović A, Adzić M, Spasić SD, Radojcić MB. Antitumor effects of a natural anthracycline analog (Aloin) involve altered activity of antioxidant enzymes in HeLaS3 cells. Cancer Biol Ther. 2007;6(8): 1211 -1216. doi:10.4161/cbt.6.8.4383. Medline

42. Wang YR, Yang SY, Chen GX, Wei P. Barbaloin loaded polydopamine-polylactide-TPGS (PLA-TPGS) nanoparticles against gastric cancer as a targeted drug delivery system: Studies in vitro and in vivo.Biochem Biophys Res Commun. 2018;499(1):816 . doi:10.1016/i.bbrc.2018.03.069. Medline

43. Liu JX, Zhang JH, Li HH, et al. Emodin induces Panc-1 cell apop tosis via declining the mitochondrialmembranepotential. OncolRep.2012;28(6): 1991 -1996.doi: 10.3892/or.2012.2042. Medline

44. Yan YY, Zheng LS, Zhang $X$, et al. Blockade of Her2/neu binding to Hsp90 by emodin azide methyl anthraquinone derivative induces proteasomal degradation of Her2/neu.Mol Pharm. 2011 ;:8(5):1687-1697. doi: 10.1021/mp2000499. Medline

45. Yu CX, Zhang $X Q$, Kang $L D$, et al. Emodin induces apoptosis in human prostate cancer cell LNCaP.Asian J Androl. 2008; 10(4):625634. doi:10.1111/i.1745-7262.2008.00397.x. Medline

46. Zhang L, Lv R, Qu X, Chen X, Lu H, Wang Y. Aloesin Suppresses Cell Growth and Metastasis in Ovarian Cancer SKOV3 Cells through the Inhibition of the MAPK Signaling Pathway. Anal Cell Pathol. 2017;2017:1-9. doi:10.1155/2017/8158254. Medline

47. Lee $\mathrm{KH}, \mathrm{Kim} J \mathrm{H}, \operatorname{Lim} \mathrm{DS}, \mathrm{Kim} \mathrm{CH}$. Anti-leukaemic and anti-mutagenic effects of dil2-ethylhexyl)phthalate isolated from Aloe vera Linne.J Pharm Pharmacol. 2000;52(5):593-598. doi: $10.1211 / 0022357001774246$. Medline

48. Lee $\mathrm{KH}$, Hong $\mathrm{HS}$, Lee $\mathrm{CH}, \mathrm{Kim} \mathrm{CH}$. Induction of apoptosis in human leukaemic cell lines K562, HL6O and U937 by diethylhexylphthalate isolated from Aloe vera Linne.J Pharm Pharmacol. 2000:52(8): 1037-1041. doi: $10.1211 / 0022357001774778$. Medline

49. Yagi A, Marino K, Nishioka I, Kuchino Y. Aloe mannan, ploysaccharide, from Aloe arborescens var. natalensis.Planta Med. 1977;31(01):17-20. doi:10.1055/s-0028-1097482. Med$\underline{\text { line }}$

50. Jeong HYKJ, Hwang SJ, Rhee DK. Anticancer Effects of Aloe on Sarcoma 180 in ICR Mouse and on Human Cancer Cell Lines. YAKHAK HOEII. 1994;38(3):31 1 -32 1.

51. Sampedro MC, Artola RL, Murature M, et al. Mannan from Aloe saponaria inhibits tumoral cell activation and proliferation. Int Immunopharmacol. 2004;4(3):41 1-418.doi:10.1016/i.intimp.2003.12.016. Medline

52. El-Shemy $H$, Aboul-Soud M, Nassr-Allah A, Aboul-Enein K, Kabash A, Yagi A. Antitumor properties and modulation of antioxidant enzymes' activity by Aloe vera leaf active principles isolated via supercritical carbon dioxide extraction.Curr Med Chem. 2010;17(2):129-138. doi: $10.2174 / 092986710790112620$. Medline

53. Cárdenas C, Quesada AR, Medina MA. Evaluation of the anti-angiogenic effect of aloe-emodin. Cell Mol Life Sci. 2006;63(24):3083-3089.doi: 10.1007/s00018-006-6399o. Medline

54. Kocik J, BałanBJ, Zdanowski R, Jung L, Skopińska-Różewska E, Skopiński P. Feeding mice with Aloe vera gel diminishes L-1 sarcoma-induced early neovascular response and tumor growth.Cent Eur J Immunol. 2014;1(1):14-18. doi:10.5114/ ceii.2014.42116. Medline

55. Subo jP, Babykutty S, Valiyaparambil Gopi DR, Nair RS, Srinivas P, Gopala S. Aloe emodin inhibits colon cancer cell migration/ angiogenesis by downregulating MMP-2/9, RhoB and VEGF via reduced DNA binding activity of NF-kappaB. European journal of pharmaceutical sciences: official journal of the European Federation for Pharmaceutical Sciences.2012;45(5):58 1-591.

56. Pan $Q$, Pan $H$, Lou $H, X \cup Y$, Tian L. Inhibition of the angiogenesis and growth of Aloin in human colorectal cancer in vitro and in vivo.Cancer Cell Int. 2013;13(1):69. doi:10.1186/14752867-13-69. Medline

57. SinghN, BabyD, RajguruJ, PatilP, ThakkannavarS, PujariV. Inflammation and cancer.Ann Afr Med. 2019;18(3):121-126. doi: 10.4103/aam.aam 56 18. Medline 
58. Davis RH, Kabbani JM, Maro NP. ALOE VERA AND INFLAMMATION.Proceedings of the Pennsylvania Academy of Science. 1986;60(1):67-70

59. Vázquez B, Avila G, Segura D, Escalante B. Antiinflammatory activity of extracts from Aloe vera gel.J Ethnopharmacol. 1996;55(1):69-75. doi: 10.1016/S0378-8741196/01476-6. Medline

60. Davis RH, Parker WL, Samson RT, Murdoch DP. The isolation of an active inhibitory system from an extract of aloe vera.J Am Podiatr Med Assoc. 1991;81(5):258-261.doi:10.7547/8750731581-5-258. Medline

61. Ma Y, Tang T, Sheng $L$, et al. Aloin suppresses lipopolysaccharideinduced inflammation by inhibiting JAK ISTAT1/3 activation and ROS production in RAW264.7 cells. Int J Mol Med. $2018: 42(4)$ : 1925 -1934.doi: 10.3892/iimm.2018.3796. Medline

62. Gao R, Wu X, Huang $Z$ et al. Anti-tumor effect of aloe-emodin on cervical cancer cells was associated with human papillomavirus E6/E7 and glucose metabolism. OncoTargets Ther. 2019;12:3713-3721. doi:10.2147/OT.S182405. Medline

63. He ZH, Huang YQ, Weng SF, et al. [Effect of Aloe emodin on invasion and metastasis of high metastatic breast cancer MDAMB-231 cells]. Zhong Yao Cai. 2013;36(9): 148 1-1485 Medline.

64. Chen YY, Chiang SY, Lin JG, et al. Emodin, aloe-emodin and rhein inhibit migration and invasion in human tongue cancer SCC4 cells through the inhibition of gene expression of matrix metalloproteinase-9. Int J Oncol. 2010;36(5): 111 13-1 120 Medline.

65. Yonehara A, Tanaka Y, Kulkeaw K, Era T, Nakanishi Y, Sugiyama D. Aloe vera Extract Suppresses Proliferation of Neuroblastoma Cells In Vitro.Anticancer Res. 2015;35(8):4479-4485 Medline.

66. Tabolacci $C$, Lentini A, Mattioli $P$, et al. Antitumor properties of aloe-emodin and induction of transglutaminase 2 activity in B16-F10 melanoma cells.Life Sci. 2010;87(9-10):316-324. doi:10.1016/i.Ifs.2010.07.003. Medline

67. Guo J, Xiao B, Liu Q, Gong Z, Le Y. Suppression of C-myc expression associates with anti-proliferation of aloe-emodin on gastric cancer cells. Cancer Invest. 2008;26(4):369-374. doi:10.1080/07357900701788130. Medline

68. Lu GD, Shen HM, Ong CN, Chung MCM. Anticancer effects of aloe-emodin on HepG2 cells: Cellular and proteomic studies.Proteomics Clin Appl. 2007; 1(4):410-419.doi:10.1002/ prca.200600798. Medline

69. Lee H, Lin C, Yang W, Leung W, Chang S. Aloe-emodin induced DNA damage through generation of reactive oxygen species in human lung carcinoma cells. Cancer Lett. 2006;239(1):55-63. doi:10.1016/i.canlet.2005.07.036. Medline

70. Özenver N, Saeed M, Demirezer LÖ, Efferth T. Aloe-emodin as drug candidate for cancer therapy. Oncotarget. $2018 ; 91251: 17770-17796$.doi: 10.18632/oncotarget. 24880. Medline

71. Chen YY, Chiang SY, Lin JG, et al. Emodin, aloe-emodin and rhein induced DNA damage and inhibited DNA repair gene expression in SCC-4 human tongue cancer cells. Anticancer Res. 2010;30(3):945-951 Medline.

72. Lissoni P, Rovelli F, Brivio F, et al. A randomized study of chemotherapy versus biochemotherapy with chemotherapy plus Aloe arborescens in patients with metastatic cancer.In Vivo. 2009;23(1): 171-175 Medline.

73. Majumder R, Parida P, Paul S, Basak P. In vitro and in silico study of Aloe vera leaf extract against human breast cancer. Nat Prod Res. 2019;1-4. doi:10.1080/14786419.2018.15348
48. Medline

74. Su CK, Mehta V, Ravikumar L, et al. Phase II double-blind randomized study comparing oral aloe vera versus placebo to prevent radiation-related mucositis in patients with head-and-neck neoplasms. Int J Radiat Oncol Biol Phys. 2004;60(1):171-177. doi:10.1016/i.iirobp.2004.02.012. Medline

75. Acharya JK, Vyas S, Purohit R, Mathur R, Agarwal RP. Aloe vera: a multifaceted ayurvedic herb use in palliative care of oral cancer patients. Supportive care in cancer Conference: 2018 joint meeting of the multinational association of supportive care in cancer, MASCC and the international society of oral oncology, ISOO 2018 Austria.2018;26(2 Supplement 1):S192S193.

76. Puataweepong P, Dhanachai M, Dangprasert S, et al. The efficacy of oral aloe vera juice for radiation induced mucositis in head and neck cancer patients: a double-blind placebo-controlled study.Asian Biomed. 2009:3(4):375-382.

77. Heggie S, Bryant GP, Tripcony L, et al. A Phase III study on the efficacy of topical aloe vera gel on irradiated breast tissue. Cancer Nurs. 2002;25(6):442-451. doi:10.1097/000028202002 1 2000-00007. Medline

78. Winters WD, Benavides R, Clouse WJJEB. Effects of aloe extracts on human normal and tumor cells in vitro. $1981 ; 35(1): 89-95$

79. Mizukoshi E, Kaneko S. Telomerase-Targeted Cancer Immunotherapy.Int'j Mol Sci. 2019;20(8): 1823.doi:10.3390/ iims20081823. Medline

80. Cheng $R, X_{U}$ J, Zhang $X$, Shi $Z$, Zhang $Q$, Jin $Y$. A selective and label-free strategy for rapid screening of telomere-binding Ligands via fluorescence regulation of DNA/silver nanocluster.Sci Rep. 2017;711):42629. doi:10.1038/srep42629. Medline

81 . Sun D, Thompson B, Cathers BE, et al. Inhibition of human telomerase by a G-quadruplex-interactive compound.J Med Chem. 1997;40(14):2113-2116. doi:10.1021/im970199z. Medline

82. $\mathrm{MaH}$, Li J, Yang لll, et al. [Di-2-ethylhexyl phthalate and its metabolite single-ethylhexyl phthalate affect TGF-beta 1 expression and telomerase activity in the testis of young male rats]. Zhonghua nan ke $x u e=$ National journal of andrology.2012; 18(9):783-788.

83. Wang S, Yan WW, He M, Wei D, Long ZJ, Tao YM. Aloe emodin inhibits telomerase activity in breast cancer cells: transcriptional and enzymological mechanism. Pharmacological reports PR.2020

84. Yu CS, Yu FS, Chan JK, et al. Aloe-emodin affects the levels of cytokines and functions of leukocytes from Sprague-Dawley rats. In Vivo. 2006;20(4):505-509 Medline.

85. Imanishi KI. Aloctin A, an active substance of Aloe arborescens Miller as an immunomodulator. 1993;7(7):S20-\$22.

86. Imanishi K, Ishiguro T, Saito H, Suzuki I. Pharmacological studies on a plant lectin, Aloctin A. I. Growth inhibition of mouse methylcholanthrene-induced fibrosarcoma (Meth A) in ascites form by Aloctin A.Experientia. 1981;37(11):1186-1187. doi: 10.1007/BF01989910. Medline

87. Yoshimoto R, Kondoh N, Isawa M, Hamuro J. Plant lectin, ATF1011, on the tumor cell surface augments tumor-specific immunity through activation of $T$ cells specific for the lectin.Cancer Immunol Immunother. 1987;25(1):25-30. doi:10.1007/ BF00199297. Medline

88. Harris C, Pierce K, King G, Yates KM, Hall J, Tizard I. Efficacy of acemannan in treatment of canine and feline spontaneous neoplasms.Mol Biother. 1991;3(4):207-2 13 Medline.

89. Cosmetic Ingredient Review Expert Panel. Final Report on the Safety Assessment of Aloe Andongensis Extract, Aloe Andongensis Leaf Juice, Aloe Arborescens Leaf Extract, Aloe Arborescens Leaf Juice, Aloe Arborescens Leaf Protoplasts, Aloe Barbadensis- 
Flower Extract, Aloe Barbadensis Leaf, Aloe Barbadensis Leaf Extract, Aloe Barbadensis Leaf Juice, Aloe Barbadensis Leaf Polysaccharides, Aloe Barbadensis Leaf Water, Aloe ferox leaf extract,Aloe Ferox Leaf Juice, and Aloe Ferox Leaf Juice Extract1.Int J Toxicol. 2007;26(2_suppl)(Suppl 2): 1-50. doi:10.1080/10915810701351186. Medline

90. Kumar S, Tiku AB. Immunomodulatory potential of acemannan (polysaccharide from Aloe vera) against radiation induced mortality in Swiss albino mice. Food Agric Immunol. 2016;27(11):72-

86.doi:10.1080/09540105.2015.1079594.

91. Peng SY, Norman J, Curtin G, Corrier D, McDaniel HR, Busbee D. Decreased mortality of Norman murine sarcoma in mice treated with the immunomodulator, Acemannan.Mol Biother. 1991;3(2):79-87 Medline

92. TsengHS, WangYF, TzengYM, et al. Aloe-Emodin Enhances Tamoxifen Cytotoxicity by Suppressing Ras/ERK and PI3K/mTOR in Breast Cancer Cells.Am J Chin Med. 2017:45(02):337-350. doi: 10.1142/S0192415X17500215. Medline

93. Fenig E, Nordenberg J, Beery E, Sulkes J, Wasserman L. Combined effect of aloe-emodin and chemotherapeutic agents on the proliferation of an adherent variant cell line of Merkel cell carcinoma. Oncol Rep. 2004;11(1):213-217. doi:10.3892/ or. 11.1.213. Medline

94. Mishralc. Scientific Basis for Ayurvedic Therapies. CRC PRESS2004.

95. Hussain A, Sharma C, Khan S, Shah K, Haque S. Aloe vera inhibits proliferation of human breast and cervical cancer cells and acts synergistically with cisplatin. Asian Pac J Cancer Prev. 2015; 16(7):2939-2946.doi:10.7314/APLP.2015.16.7.2939. Medline

96. Luo J, Yuan Y, ChangP, Li D, Liu Z, Qu Y. Combination of aloe-emodin with radiation enhances radiation effects and improves differentiation in human cervical cancer cells. Mol Med Rep. 2014;10(2):731-736.doi:10.3892/mmr.2014.2318. Medline

97. Tabolacci C, Rossi S, Lentini A, et al. Aloin enhances cisplatin antineoplastic activity in B16-F10 melanoma cells by transglutaminase-induced differentiation. Amino Acids. 2013;44(1):293300.doi: 10.1007/s00726-01 1-1 166-x. Medline

98. Kim YS, Lee YM, Oh Tl, et al. Emodin Sensitizes Hepatocellular Carcinoma Cells to the Anti-Cancer Effect of Sorafenib through Suppression of Cholesterol Metabolism.Int J Mol Sci. 2018;19(10):3127. doi:10.3390/iims 19103127. Medline

99. Liu $Y Q$, Meng PS, Zhang HC, et al. Inhibitory effect of aloe emodin mediated photodynamic therapy on human oral mucosa carcinoma in vitro and in vivo. Biomedicine \& pharmacotherapy = Biomedecine \& pharmacotherapie. 2018;97:697-707.

100. Lin HD, Li KT, Duan $Q Q$, et al. The effect of aloe-emodin-induced photodynamic activity on the apoptosis of human gastric cancer cells: A pilot study. Oncol Lett. 2017; 13(5):3431-3436. doi: 10.3892/ol.2017.5915. Medline

101. ChenQ, TianS, ZhuJ, et al. Exploring a Novel Target Treatment on Breast Cancer: Aloe-emodin Mediated Photodynamic Therapy Induced Cell Apoptosis and Inhibited Cell Metastasis.Anticancer Agents Med Chem. 2016;16(6):763-770. doi:10.2174/187 1520615666150821093323. Medline

102. Ahmadloo N Kadkhodaei B, Omidvari Sh, et al. Lack of Prophylactic Effects of Aloe Vera Gel on Radiation Induced Dermatitis in Breast Cancer Patients. Asian Pac J Cancer Prev. 2017; 18(4): 11 39-1 143 Medline

103. Sahebjamee $M$, Mansourian A, Hajimirzamohammad $M$, et al. Comparative Efficacy of Aloe vera and Benzydamine Mouthwashes on Radiation-induced Oral Mucositis: A Triple-blind, Ran- domised, Controlled Clinical Trial.Oral Health Prev Dent. 2015; 13(4):309-3 15 Medline.

104. Lissoni P, GianiL, Zerbini S, Trabattoni P, RovelliF. Biotherapy with the pineal immunomodulating hormone melatonin versus melatonin plus aloe vera in untreatable advanced solid neoplasms. Nat Immun. 1998; 16(1):27-33. doi:10.1159/000069427. Medline

105. Damani MR, Shah AR, Karp CL, Orlin SE. Treatment of ocular surface squamous neoplasia with topical Aloe vera drops.Cornea. 2015;34(1):87-89. doi:10.1097/ ICO.0000000000000296. Medline

106. King GK, Yates KM, Greenlee PG, et al. The effect of Acemannan Immunostimulant in combination with surgery and radiation therapy on spontaneous canine and feline fibrosarcomas.J Am Anim Hosp Assoc. 1995;3115):439-447.doi: 10.5326/1547331731-5-439. Medline

107. Tomasin R, Cintra Gomes-Marcondes MC. Oral administration of

Aloe vera and honey reduces walker tumour growth by decreasing cell proliferation and increasing apoptosis in tumour tissue. Phytother Res. 2011 ;25(4):619-623. doi:10.1002/ptr.3293. Medline

108. Liu A, Chen H, Tong H, et al. Emodin potentiates the antitumor effects of gemcitabine in pancreatic cancer cells via inhibition of nuclear factor-kB. Mol Med Rep. 2011 ; 4(2):221-227 Medline.

109. Kim I-R, Kwon H-JITR. Induction of apoptosis by Aloe vera extract in human hepatocellular carcinoma HepG2 cells. 2006;22(4):329-332.

110. Shimpo K, Chikako T, Shinzato $M$, et al. Inhibition of $N$-ethyl-N'-nitro-N-nitrosoguanidine-induced 'Duodenal Tumorigenesis in Mice by Whole-leaf Aloe arborescens Miller var. natalensis Berger.Asian Pac J Cancer Prev. 2000; 1 (4):283-288 Medline.

111 . Yeh FT, Wu CH, Lee HZ. Signaling pathway for aloe-emodin-induced apoptosis in human $\mathrm{H} 460$ lung nonsmall carcinoma cell. Int J Cancer. 2003;106(1):26-33. doi:10.1002/iic. 11185. Medline

1 12. Mijatovic S, Maksimovic-lvanic D, Radovic J, et al. Anti-glioma action of aloe emodin: the role of ERK inhibition.Cell Mol Life Sci. 2005;62(5):589-598.doi: 10.1007/s00018-005-44258. Medline

113. Huang PH, Huang CY, Chen MC et al. Emodin and Aloe-Emodin Suppress Breast Cancer Cell Proliferation through ER alpha Inhibition. Evidence-based complementary and alternative medicine : eCAM.2013;2013:376123.

114. Lee HZ. Effects and mechanisms of emodin on cell death in human lung squamous cell carcinoma. $\mathrm{Br} J$ Pharmacol. 2001; 134(1): 1 1-20. doi: 10.1038/sj.bjp.0704205. Medline

115. Dong $X, N i B, F u J$, et al. Emodin induces apoptosis in human hepatocellular carcinoma HepaRG cells via the mitochondria caspasedependent pathway. Oncol Rep. 2018;40(4): 19851993.doi: 10.3892\%or.2018.6620. Medline

116. Ying J, Xu H, Wu D, Wu X. Emodin induces apoptosis of human osteosarcoma cells via mitochondria- and endoplasmic reticulum stress-related pathways.Int J Clin Exp Pathol.2015;8(10): 12837-12844 Medline.

117. Su J, Yan Y, Qu J, Xue X, Liu Z, Cai H. Emodin induces apoptosis of lung cancer cells through ER stress and the TRIB3/NF-B pathway. Oncol Rep. 2017;37(3):1565-1572. doi: 10.3892\%or.2017.5428. Medline

118. Lin W, Zhong $M$, Yin $H$, et al. Emodin induces hepatocellular carcinoma cell apoptosis through MAPK and PI3K/AKT signaling pathways in vitro and in vivo. Oncol Rep. 2016;36(2):961-967. 
doi:10.3892/or.2016.4861. Medline

1 19. Li N, Wang C, Zhang P, You S. Emodin inhibits pancreatic cancer EMT and invasion by upregulating microRNA1271. Mol Med Rep. 2018;18(3):3366-3374.doi:10.38921 mmr.2018.9304. Medline

120. LinY, ChenW, WangZ, CaiP. Emodin promotes the arrest of human lymphoma Raii cell proliferation through the UHRF 1-DNMT3A- $\triangle \mathrm{Np} 73$ pathways.Mol Med Rep. 2017;16(5):65446551 .doi:10.3892/mmr.2017.7423. Medline

121. WangY, LuoQ, HeX, et al. Emodin Induces Apoptosis of Colon Cancer Cells via Induction of Autophagy in a ROS-Dependent Manner.Oncology Research Featuring Preclinical and Clinical Cancer Therapeutics. 2018;26(6):889-899. doi:10.3727/09 $\underline{6504017 \times 15009419625178}$. Medline

122. Zu C, Zhang $M$, Xue $H$, et al. Emodin induces apoptosis of human breast cancer cells by modulating the expression of apoptosis-related genes. Oncol lett. 2015;10(5):2919-2924. doi:10.3892/ol.2015.3646. Medline

123. Chen Y, Li J, Hu J, et al. Emodin enhances ATRA-induced differentiation and induces apoptosis in acute

myeloid leukemia cells. Int J Oncol. 2014;45(5):2076-2084. doi: 10.3892/iio.2014.2610. Medline

124. Xie MJ, Ma YH, Miao L, et al. Emodin-provoked oxidative stress induces apoptosis in human colon cancer HCT1 16 cells through a p53-mitochondrial apoptotic pathway. Asian Pac J Cancer Prev. 2014;15(13):5201-5205. doi:10.7314/APJCP.2014.15.13.5201. Medline

125. Huang FJ, Hsuuw YD, Chan WH. Characterization of apoptosis induced by emodin and related regulatory mechanisms in human neuroblastoma cells. Int J Mol Sci. 2013; 14(10):2013920156.doi:10.3390/iims 141020139. Medline

126. Yaoxian W, Hui Y, Yunyan Z, Yanqin L, Xin G, Xiaoke W. Emodin induces apoptosis of human cervical cancer hela cells via intrinsic mitochondrial and extrinsic death receptor pathway. Cancer Cell Int. 2013;13(1):71. doi:10.1186/1475-286713-71. Medline

127. Subramaniam A, Shanmugam MK, Ong TH, et al. Emodin inhibits growth and induces apoptosis in an orthotopic hepatocellular carcinoma model by blocking activation of STAT3. Br J Pharmacol. 2013;170(4):807-821. doi:10.1111/bph.12302. Medline

128. Li WY, Chan RYK, Yu PHF, Chan SW. Emodin induces cytotoxic effect in human breast carcinoma MCF-7 cell through modulating the expression of apoptosis-related genes. Pharm Biol. 201 3; 51 (9): $1175-1181$.doi:10.3109/13880209.2013.78 2322. Medline

129. Yu JQ, Bao W, Lei JC. Emodin regulates apoptotic pathway in human liver cancer cells. Phytother Res. 2013;27(2):251-257. doi: 10.1002/ptr.4703. Medline
130. Zheng ZH, Hu JD, Chen $Y Y$, et al. [Effect of emodin on proliferation inhibition and apoptosis induction in leukemic K562 cells]. Zhongguo Shi Yan Xue Ye Xue Za Zhi. 2009; 17(6): 14341438 Medline.

131. Zheng HY, HuJ D, Zheng ZH, et al. [Emodin induces leukemic $\mathrm{HL}-60$ cells apoptosis probably by inhibiting Akt signal pathway]. Yao Xue Xue Bao. 2007;42(1 1): 11 42-1 146 Medline.

132. Su YT, Chang HL, Shyue SK, Hsu SL. Emodin induces apoptosis in human lung adenocarcinoma cells through a reactive oxygen species-dependent mitochondrial signaling pathway. Biochem Pharmacol. 2005;70(2):229-241.doi:10.1016/i. bcp.2005.04.026. Medline

133. Chen YC, Shen SC, Lee WR, et al. Emodin induces apoptosis in human promyeloleukemic $\mathrm{HL}-60$ cells accompanied by activation of caspase 3 cascade but independent of reactive oxygen species production. Biochem Pharmacol. 2002;64(12): 17131724.doi:10.1016/S0006-2952102101386-2. Medline

134. Srinivas G, Anto RJ, Srinivas P, Vidhyalakshmi S, Senan VP, Karunagaran 'D. Emodin induces apoptosis of human cervical cancer cells through poly(ADP-ribose) polymerase cleavage and activation of caspase-9. Eur J Pharmacol. 2003;473(2-3): 117 125 . doi:10.1016/50014-2999/03101976-9. Medline

135. Jing X, Ueki $N$, Cheng J, Imanishi $H$, Hada T. Induction of apoptosis in hepatocellular carcinoma cell lines by emodin.Jpn J Cancer Res. 2002;93/8):874-882. doi: 10.1111/i.1349-7006.2002. tb01332.x. Medine

\section{Peer Reviewed}

Competing Interests: None declared.

Funding: This study was not funded

Received: 20 Jun 2019; Accepted: 06 October 2020

Cite this article as Manirakiza A, Irakoze L, Manirakiza S. Aloe and its Effects on Cancer: A Narrative Literature Review. East Afr Health Res J. 2021;5(1):1-16. https://doi.org/10.24248/ eahrj.v5il.645

(C) Manirakiza et al. This is an open-access article distributed under the terms of the Creative Commons Attribution License, which permits unrestricted use, distribution, and reproduction in any medium, provided the original author and source are properly cited. To view a copy of the license, visit http:// creativecommons.org/licenses/by/4.0/. When linking to this article, please use the following permanent link: https://doi. org/10.24248/eahrj.v5il.645 